\title{
Critique of ethnic nationalism in the teachings of Said Nursi: A study of nationalism and the question of Islam in Bangladeshi identity
}

\author{
Sumaiya Rabeya and Mohammad Hossain \\ MSc. Student \\ International Islamic University Malaysia (IIUM), Malaysia
}

\begin{abstract}
Bediuzzaman Said Nursi, a strong proponent of Muslim unity, was always against what he called negative nationalism in Muslim societies. While he believed that nationalism could play a positive role in arousing compassion of Muslims, he also warned of its potential drawbacks and adverse consequences as a tool for domination and causing harm. Ethnic nationalism is primarily seen in highly homogenous societies throughout the world today. Bangladeshi nationalism, as developed by its proponents, has however, failed to be inclusive, and instead works within a framework which tends towards exclusion. This paper, through a discursive discussion of historical narratives and aspects of identity formation, argues that recent manifestations of the ills of Bangladeshi nationalism, stems from deeper issues related to failure of resolving the place of religious identity, mainly Islamic identity, within the Bangladeshi identity. This has led to aspects of negative nationalism, such as deeply polarized society, and aided in maintaining the divisive dichotomy of the secular and religious within the nation state in Bangladesh.
\end{abstract}

Keywords Bediuzzaman Nursi, Islam, Ethnic nationalism, Bangladesh

Paper type Case study

\section{Introduction}

Nationalism is one of the most potent forces of state formation of our age, so much so that it is almost unthinkable for the common uninitiated observer to imagine that this was not always the case. While the origins of nationalism go back to the 18th century, the nation state, which is based upon nationalism, is a fruit of the socio-political developments of 19th century Europe, and came to full fruition after the First World War. Ethnic nationalism, as seen in many countries today, is a form a nationalism that is usually based upon linguistic-ethnic aspects, and is most visible in states that

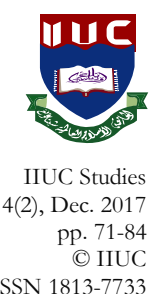


have a homogeneity in terms of ethnicity or language. The diffusion of Europe's colonial influence throughout Muslim lands has made nationalism one of the foremost ideologies in the modern world.

Bediuzzaman Said Nursi (1877-1960) was a famous Muslim thinker of the twentieth century, dedicated in restoring the Islamic teachings in the society by renewing the knowledge of Islam as authentically as presented in the Quran and Sunnah. He was born in the territory of modern Turkey, was of Kurdish ethnic origin and from a time post collapse of Ottoman Empire when the idea of state and sovereignty became prevalent, proposing substitute to the traditional Muslim Ummah identity for Muslims. Eventually, the nation state of Turkey was built upon strong nationalistic foundations and secular values under the aegis of Kamal Ataturk, the mixed legacy of which Nursi himself experienced firsthand.

Nursi created a framework from Islamic knowledge to counter the modern world issues through methods that were nonviolent and individualist in nature (Nereid, 2000). Few Muslims scholars of the time were able to make such great an impact on the society through Islamic renewal like Nursi, who was also known as "Mulla Said" or the "Wonder of the Age" for his impeccable intellect (Abu Rabi, 2008). The formation of the contemporary Turkish Muslim identity is indebted essentially to the Nursi Movement, which was led, after the fall of the Ottoman Caliphate, by Bediuzzaman Said Nursi and his devoted followers. But the erstwhile government, under the leadership of Mustafa Kamal Ataturk in his newly formed secular state of Turkey, responded with persecution and confinement of Nursi and his followers throughout his life. Despite the continuous struggle, Nursi was steadfast in leading a productive and optimistic struggle. He explained;

The sword is to be drawn against the external enemies, it may not be used internally. Our only salvation at this time is to offer illumination and guidance through the truth of the Quran and belief; it is to get rid, of our greatest enemy, ignorance.

In light of this, he promoted the term "Jihad of word" (Ibrahim, 2005).

The struggle of Nursi and his message has resonated with Muslims worldwide, making him a beloved figure amongst them. The ills of the society that he so struggled to reform and tackle are still prevalent in many societies and nations worldwide, particularly through the negative effects of ethnic nationalism. Bangladesh, a nation born in 1971, emerged from failures of integration within the framework of Muslim nationalism. However, the ethnic nationalism that replaced it was still highly exclusionary, leading to tensions within a society that is highly homogenous; almost $98 \%$ of the people hail from Bengali ethnicity. 
Despite this homogeneity, Bangladeshi nationalism, as propagated by a section of its proponents, has largely positioned itself in a position antithetical to Islam, as practiced and expressed by the common people. The resulting tensions have led to the development of a polarized society, and narrow-mindedness in terms of government policies, whereby serious divisions have been fostered, and the 'Other' have been victimized.

\section{Nationalism: definition and discussion}

Nationalism initially emerged as an ideology, a belief, creed or political dogma in the contemporary scholarships that preached freedom from the shackles of long imposing dynasty rule, achieving self-governance and as an expression of sovereignty over a certain geographic territory (Triandafyllidou, 1998). The term nationalism was coined by the famous German philosopher Johann Gottfried Herder in the late 1770s, and he described it as a "belief that nations will benefit from, acting independently rather than collectively, emphasizing national rather than international goals." (Bensaid, 2017). Furthermore, nationalism is also described by another author as;

[a]...state of mind, permeating the large majority of a people and claiming to permeate all its members; it recognises the nation-state as the ideal form of political organisation, and nationality as the source of all creative and cultural energy and economic wellbeing. The supreme loyalty of man is therefore due to his nationality, and his own life is supposedly rooted in and made possible by its welfare (Kohn, 1990, as cited in Carter, 1994).

With the formation of nation states throughout the world, the fall of different empires was facilitated and inspired by this ideology, and it soon transformed into the fabric of identity and a sense of belonging for the masses; an identity that was constructed carefully by those who hold the power.

After the demise of the last Islamic empire- the Ottomans, Western social scientists have largely held the European transformation from the Church-state to nation state as the standard for modern civilization and "an inevitable stage in the universal ideological development," regardless of the context or the inclinations on the ground. Similar to other initially reluctant nations (Czech, Hungarian, Polish, Greek, etc.), the adaption of nationalism was credited for enabling Muslims (who are now divided into separate nations) to enter, from the "insignificant corner," to the phase of "social progress" and "middle-class capitalism" (Kohn, 1990 cited in Carter, 1994). Western philosophers celebrated their invention of the ideology, which quickly became a cornerstone for civilization in the rest of the world. Interestingly, even though the concept of nationalism is one of 
the core reasons for many of the disputes in politics, including the creation of homogenous culture and features as a measuring tool for acceptance, the founder of the term, Herder, who is considered as the first theoretical scholar for nationalism, viewed it as "one of the avatars of contemporary multiculturalism" (Taylor, 1994).

However, scholars widely known as proponents of nationalism, like Hans Kohn and George Orwell, did warn the world of the effects of nationalism. One of the criticisms the ideology faces is the distortion of moral judgement that nationalism inflict upon its believers. Orwell (1953) explained, "Because of nationalism we tend to divide the world into an "us" and "them"; terms like "freedom fighter" and "terrorist" become secondary to our own national sympathies; and a form of moral relativism prevails". Similarly, White (2005), in his writing, mentioned that there are significant "moral dangers of nationalism," and like many scholars he also stated that "nationality and national differences are not really differences that should have any significance, for they are accidental determinations of who we are, like blood-type, race or even religion".

\section{Said Nursi's understanding of nationalism and its ills}

Bediuzzaman Said Nursi acknowledged the widespread uprising of nationalistic sentiments that was evident in his times, especially with the emergence of Kamal Ataturk and his strong Turkish identity propaganda. Although, it was hard to distinguish the enforced secularism from nationalism due to the reformation movement of the time, Nursi articulated nationalism as a product in diverse form that exist throughout human history, not only as a product of the modern European thought. Unlike most Islamic scholars, Nursi had a rare view point towards reconciling nationalism as a valid and reasonable sentiment in the modern world, and to the Muslim world as well (Akhmetova, 2013). An analysis of the third and fourth matters in the Twenty Sixth Letter of the Risale-eNurshows that he understood that nationalism could be both positive and negative. He had this ability to differentiate the positive and negative aspects of nationalism, dividing it of positive and negative types without overbearing with moral policing of the thought, which is precisely the approach for most of the Islamic scholars even today. Warning of the ills of negative nationalism leading to divisions in the third matter of the Twenty Sixth Letter, he warned that the idea of nationalism as espoused by the "...cunning European tyrants in particular awaken this (nationalism) among Muslims in negative fashion so they may divide them up and devour them.” (26th Letter, Risale-e-Nur, n.d.) 
Bediuzzaman Said Nursi and the Nur movement that was influenced by his thoughts brought up issues of importance for the broad-spectrum understanding of the relationship among state and faith in an Islamic perspective. In the writings of Nursi, 'nation' (millet) and 'nationhood' (milliyet) were used in light of the Arabic meanings of these words respectively. Interestingly the word 'millet', Arabic for nation, was generally used by Muslim scholars to represent a "religion" or "membership" which was synonymous to the word "ummah" (Akhmetova, n.d.). Nursi, being a pragmatic thinker, believed in attaining the ability to mold oneself with the changing society, especially when that change is inevitable. Since, the new idea of sovereign nation took hold in post-Ottoman Turkey, instead of opposing the inevitable, it was important to pause and ponder what it really meant for Islam. According to Nursi, the concept of sovereignty of nation was not necessarily at odds with the Sharia. Instead, it could be a privilege that Muslims could enjoy, as well as a responsibility that they could preserve. To Nursi, if taken positively, nationalism could be a "vehicle to achieve material progress," which could facilitate the means to "uphold the supremacy of Islam" (Ibrahim, 2005).

Nursi believed that the ills of nationalism were not entirely a firsthand problem of his time, but that it had existed all through human history, stems when the individuals considers a particular race to be superior, or gives priority to race over religion. He mentioned the examples of Umayyad Dynasty and how it's over biased nepotism resulted in their disastrous ending. Since the ideologies of racialism and nationalism do not ensure justice and equality, Nursi opined, the Umayyad became tyrants and scared off the other nations. He discusses the ills of nationalism among Turks in the Fourth Satanic Stratagem of the Twenty Ninth Letter, detailing the negative nationalism in the garb of Turkism of his time, which he says led to the destruction of the Turks, whom he divides into six groups (29 th Letter, Fourth Satanic Stratagem). Hence, negative nationalism "flourishes through harming others and is nourished through devouring others" (Bensaid, 2017).

Nationalism can only bring wellbeing if Muslims enable themselves to break free from the egoistic thought that make them feel supreme to others. However, the experiences he witnessed told of a different reality. It was important to make the people of faith realize that the sense of identity that was being instilled into the mind of Muslims was a constructed reality, which would bring no good but only evil. As a way out from this problem, he emphasized on the unity between Muslims, in particular that feeling of brotherhood called 'ummah', as exemplified in 
the Damascus sermon, where he emphasized the unifying power of Islamic nationhood in the face of the seeds of enmity that were being attempted to be sown between the Turks and Arabs:

Freedom in accordance with the Shari'aand the consultation enjoined by the Shari'a have demonstrated the sovereignty of our true nationhood. The foundation and spirit of our true nationhood is Islam. In so far as they have carried the standard of the Ottoman Caliphate and Turkish army in the name of that nationhood, the two true brothers of Arab and Turk are like the shell and citadel of the nationhood of Islam, and the sentries of that sacred citadel. Thus, through the bond of this sacred nationhood, all the people of Islam become like a single tribe. Like the members of a tribe, the peoples and groups of Islam are bound and connected to one another through Islamic brotherhood (The Damascus Sermon, n.d.).

Based on the above premise, we can now move on to explore and discuss the developments and aspects of Bangladeshi nationalism, in order to evaluate it according to the views of Bediuzzaman Nursi. This will be important in understanding the recent trajectory of events in Bangladesh, and will help in evaluating the crisis of identity found among Bangladeshis today, as discussed in the following section.

\section{Case Study}

\section{Nationalism in Bangladesh}

The independence of Bangladesh in 1971 opened a new era of nationalist identity based primarily on language, unlike in the earlier period, where the two-nation theory, identifying Muslims of India as a separate nation, was described as the chief basis of the Partition in 1947, leading to the formation of Pakistan and India. While most social scientists tend to look at the case of the development of Bangladeshi nationalism as being a reaction to the failure of Muslim nationalism in post-1947 Pakistan, Bangladeshi nationalism is actually a product of ethno-linguistic developments based upon the Bengali identity, which was propagated by a class of intellectuals and secular educated elite in the aftermath of the Partition of 1947. Bengali identity based Bangladeshi nationalism was a kind of territorial nationalism which was fostered by its proponents as the mechanism to achieve a separate independent homeland for Bengalis living in East Pakistan. Since Bangladeshi nationalism developed at a later stage after the 1970's, it is important that we understand the beginnings of the Bengali identity upon which Bangladeshi nationalism was later developed. Throughout the initial formation stages of this concept by the secular educated Bengali elites, they failed to address some crucial questions - What was the place of overall religious identity in the Bengali identity? What was the place of Islam, as the religious identity of the 
majority Bangla speaking people in East Pakistan, in the Bengali identity? As we will later see, the inability to address such questions by the secular educated elite who were initially involved with the construction of this identity, and who later became the political ruling class in Bangladesh, ultimately led to the wedging of contradictions and ills within the concept of Bangladeshi nationalism in the long run, comprising of a dichotomy between the state and religion. In retrospect, these ills lead to the characterization of Bangladeshi nationalism over time as a negative type of nationalism as per the understanding of nationalism by Nursi.

\section{Islam and Bengali identity until 1947}

A good place to start any discussion of the Muslim Bengali identity would be Rafiuddin Ahmed's The Bengal Muslims 1871-1906: A Quest for Identity. In this book, he outlines the role of Islam in fostering a unique identity of the Muslims in Bengal, albeit from a highly critical point of view. From late 19th century onwards, the two major forces working within the Muslim society in Bengal were the religious preachers - the mullahs keen on Islamizing the peasantry, and the institutional and political changes introduced by the colonial administration that favoured some over others. While the policies of the colonial administration mainly affected the city dwellers and the elite, the poorer sections of the society living in the countryside were more influenced by the religious reform movements, which contributed to a renewed interest in Islam among ordinary rural people. This led to a formation of a cohesive identity based on Islam among the rural people, or the atrap, which was not really due to the direct initiative of the ashraf or the Muslim elite, who were more affected by the institutional and political policies of the colonial administration that favoured Hindu elites (Ahmed, 1981).

The ashraf elite, on the other hand, had much to gain from this unity based on religious identity among the atrap, and were able to successfully utilize the mass sentiment whenever necessary, through skillful manipulation of symbols and ideological propaganda, to which the rural people were receptive, towards the creation in the mass mind an awareness of distinct identity through culture and lifestyle, separate from the Hindu polity and the Hindu bhadralok, the loyal byproduct of the policies of favourable representation of the Hindu upper castes through the British policy of 'divide and rule'. It was amidst this atmosphere of rising tensions, fueled by a general neglect of Muslim subjects and the long standing socio-political discriminations against them, that the seeds for Muslim nationalism were sown amongst the Muslims of Bengal, which ultimately led to the creation of Pakistan in 1947 (Ahmed, 1981). 


\section{Muslim nationalism and rise of Bengali nationalism (1947-1971)}

The creation of Pakistan in 1947 was accompanied by high hopes among Muslims in Bengal for a better future, both politically and economically. In fact, it was the Muslims of Bengal who had been the strongest proponents of the idea of Pakistan; they voted overwhelmingly in favour of the Muslim League in the 1946 elections. However, the partition did not help much in improving the economic condition of the masses. Most opportunities remained in the hands of the Urdu-speaking elite, and only a few opportunities in administration and economy were with the local bourgeois in East Pakistan. The political manifestations of Bengali resentment, mostly the demands of the Bengali Muslim bourgeois and the educated middle class, many of whom were secular educated, culminated in the making demands that reflected their frustrations at lack of opportunities, such as the demand for the recognition of Bengali language and demands for autonomy. In time, the tensions grew stronger, and the Six-Points program of 1966 put forward to the erstwhile government for constitutional guarantees for power sharing reflected this, since it reflected the aspirations of the middle class and upper middle class. At the high point of tensions, the political programme of the Awami League, the party dominant in East Pakistan, was geared towards mobilization of the masses, through propaganda, to stand up to the exploitative nature of the 'Punjabis'; it made sense to the masses and the Awami League swept the elections of 1970 upon a tide of Bengali nationalism fueled by the narrative of exploitation and accompanying symbols and propaganda. The refusal of the militarybureaucratic and business elite of West Pakistan to share power with the Bengali counter-elite, even after the decisive victory of 1970 elections, led ten-month long war of independence which led to the independence of Bangladesh. This conflict was touted by many, such as Rounaq Jahan and others, as being due to rise of Bengali nationalism. However, Rafiuddin Ahmed describes the process as being more complex than simplified narratives, since ethno-linguistic identity was not as strong a force as the Islamic identity of the common people, who were generally far removed from the debate of the clash of the identities between Muslim and Bengali nationalism, and generally did not see their culture and way of life as being 'antithetical' to Islam as such (Ahmed, 1990). It is perhaps the realization of this fact that Bengali nationalism, as expounded by its proponents among the educated elite, had to thrive upon a narrative of exploitation and use symbols. In retrospect, it did not deal with the issue of Islam and its importance in the lives of common people, but rather sought to portray Islam as an 'Other', as was observed in the post-independence period of Bangladesh. It was perhaps this very dichotomy and feeling of superiority 
constructed through negative portrayal of the religious 'Other' that Nursi warns of in his discussion on the ills of nationalism.

\section{Islam and rise of Bangladeshi nationalism in post-1971 Bangladesh}

The transformation of Bengali nationalism to Bangladeshi nationalism in post 1971 Bangladesh is a fascinating one, and has been well documented and debated (Riaz, 2002; Riaz, 2003; Hossain \& Khan, 2006). However, while such analyses tend to view the transformation from historical, political and constitutional perspectives, they collectively tend to fall into the trap of vilifying the religious 'Other' when branding Bangladeshi nationalism as simply 'unconstitutional', 'imposed' or a 'phenomenon creating a rift within an imagined community', i.e. a community held together by Bengali nationalism. While a detailed discussion of such points is necessary to understand the complexities surrounding issues in national identity, the focus of this article and the lack of space do not allow for that. However, it suffices to say that, in general, the issue of Islam, and its place in Bangladeshi national identity remains foggy and contested, mainly due to two reasons, constitutional constraints, and the role of a section of secular intellectuals working on the interpretation of Bengali identity as a secular construct.

\section{Constitutional constraints shaping Bangladeshi national identity}

A major reason for casting the role of religion as the undesired 'Other' in Bangladeshi nationalism stems for the ambiguity regarding its status in national identity in the Bangladesh constitution. According to the Bangladesh constitution, secularism is one of its key principles. The 1972 constitution of Bangladesh, drafted by the secular elite, enshrined the principle of 'secularism' as one of the founding principles of Bangladesh, alongside nationalism, socialism and democracy. Although Islam, the religion of a majority of the people of the country was not given much of a space in the new constitution, since it contradicted with its secular principles. Scholars such as Maniruzzaman (1990) note that secularism was not enforced by the president, Sheikh Mujibur Rahman himself, since it did not receive public acceptance in either state controlled media or education, which were important tools at the hands of the state to construct its brand of nationalism (Mohsin, 2004). Instead, recordings of public speeches by Sheikh Mujibur Rahman often include stressing upon his religious identity as a Muslim and the frequent use of Islamic expressions (Riaz, 2003). In the course of respective administrations under Ziaur Rahman and HM Ershad, secularism was deleted from the Constitution and Islam was declared as the state religion through an 
amendment to the Constitution. Later, the principle of secularism was restored by the Bangladesh Parliament in 2011, and the amendment which declared Islam as the state religion was challenged in 2016 at the Supreme Court, but was dismissed. Therefore, presently, the constitution has the contradictory provisions of both 'secularism' as a principle, alongside the status of Islam as the 'state religion', not just fuelling debates on national identity, but perhaps also reflecting a confused, contested and unresolved understanding of the role of religion in identity formation.

\section{Role of intellectuals: Portrayal of Islamism as terrorism as the 'Other' of Bangladeshi national identity}

Through assessment of the work of a section of secular intellectuals in Bangladesh, it can also be seen that Islam is being cast as the 'Other' of Bangladeshi national identity. In this regard, the use of value-loaded terms such as "Islamic resurgence" (Hashmi, 2004), "Islamization" (Mohsin, 2004), and the more recent "political Islamists" and "political Islam" (Riaz \& Fair, 2011) tend to portray Islam as the 'Other' of the Bangladeshi identity, creating and sustaining a dichotomy that, although may be lacking in substance on ground, inform the media and the world about Bangladeshi society and identity. Such use of labels has proliferated in recent times with the global rise in the phenomena of extremism and terrorism, especially in the post 9/11 period, making Bangladesh appear as a hub for activities of Islamic terror, when such is clearly untrue, looking at the largely peaceful and religiously harmonious nature of the Bangladeshi society.

Perhaps, the clearest manifestation of this 'Othering' can be seen in the events surrounding the recently held war crimes trials of the 1971 independence war which had led to the formation of Bangladesh as an independent country. These include the hanging of several political opposition Islamist and nationalist leaders, and polarization of public opinion through huge street protests and demonstrations for and against the trials over the past several years. While there is a dearth of studies on how the war crimes trials have affected and continue to affect identity formation, few can contest the fact that it has affected the dynamics of identity formation, including the creation of rifts in the imagined community' of Bangladeshi nationalism through formation and perpetuation of a disloyal and non-conformist Islamist 'Other'. The dominant narrative regarding the war crimes trial suggests that these trials aim to free the nation from its scandalous past, and that the "crimes against humanity" cannot go unpunished (Islam \& Islam, 2018). The narrative has its ideological roots in the assertion of the arbitrary 
dichotomy of pro-liberation and anti-liberation forces in Bangladesh since 1971. Fairly simplistic and prone to rash political use by its proponents, it fails to take into question, or rather ignores, subsequent developments in Bangladesh history where currently accused 'anti-liberation' elements such as Jamaat-e-Islami played definite roles, such as the pro-democracy antiErshad movement of the 90 's, or the fact that political Islamists have participated regularly in national elections and in government throughout the years. While almost the entire Jamaat leadership have been hanged in these trials, a whole second or third generation of political Islamists and their supporters, a significant part of the Bangladeshi population, have been identified as 'anti-liberation' a tag that continues to fuel current Awami League government actions such as human rights abuses, stifling of media and opposition, etc. and narratives such as anti-terrorism and 'for upholding the values of the liberation war'.

The exclusion of Islamists from public life and their portrayal as the 'Other' by the Bangladeshi government, leading to the larger narrative of labelling of Islam and its symbols as the 'Other' of Bangladeshi national identity is bound to have a negative impact on national identity formation. In this regard, associating the Islamists with 'anti-liberation' and terrorism only jeopardizes the question of Islam in the Bangladeshi identity, and only helps in casting Islam as the religious 'Other' of Bangladeshi nationalism.

\section{Conclusion}

Nursi's message on nationalism was that, given the right attitude and policies, it could play a positive role towards fostering progress in Muslim societies. However, failure to realize the right attitude and policies could lead to disastrous consequences, which is strongly evident in the case of Bangladesh and its brand of ethnic nationalism. An interesting point to note is that Bengali identity, as practiced and understood by Bengali Hindus in West Bengal, is not at odds with either Indian nationalism or the Hindu faith. This is not the case in Bangladeshi nationalism, which is also based on the Bengali identity, but is at odds with Muslim identity, attitudes and aspirations of the Bengali-speaking Muslim people, which is an indication of a serious underlying anomaly in the understanding of Bangladeshi nationalism by its proponents. It is manifested in like within the actions of the Bangladeshi government, especially through characterization of symbols and attitudes related to Islam as the 'Other', a good indication of which is the current narrative of Islamic terrorism and the vilification of opposition Islamists in Bangladesh. 


\section{IIUC Studies, 14(2)}

Only a sincere re-evaluation of historical narratives and a radical socio-cultural realignment of the understanding of Bangladeshi nationalism with Islam and Islamic values can foster a transformation towards a better future. It is highly recommended that the proponents of Bangladeshi nationalism understand the message of Nursi, particularly his warnings on the ill effects of negative nationalism, and work towards aligning their thoughts and understanding with the aspirations of the common people of Bangladesh towards creation of an identity that strives to include, and not exclude, to be proactive, and not reactive, in both theoretical narrative and action.

\section{References}

26 $6^{\text {th }}$ Letter, Third Topic. (n.d.). Retrieved from http://www.erisale.com/index.jsp?locale= en\#content.en.202.372

$29^{\text {th }}$ Letter, Sixth Section, Fourth Satanic Stratagem. (n.d.). Retrieved from http://www.erisale.com/index. jsp?locale=en\#content.en.202.482

Abu-Rabi', I. M. (2008). Spiritual dimensions of Bediuzzaman Said Nursi's Risale-I Nur. SUNY Press.

Ahmed, R. (1981). The Bengal Muslims 1871-1906: A quest for identity. Delhi: Oxford University Press.

Ahmed, R. (1990). Religion, Nationalism and Politics in Bangladesh. Delhi: South Asian Publishers.

Akhmetova, E. (2013). The impact of nationalism on civilisational development and human security: Works of Said Nursi and Musa Jārullāh. Islam and Civilisational Renewal, 4(4), 615-633.

Akhmetova, E. (n.d.). Nationalism in the Modern World: From the viewpoint of Bediuzzaman Said Nursi. Retrieved from http://www.bediuzzamansaidnursi.org/en/icerik/nationalism-modernworld-viewpoint-said-nursi

Bensaid, B. (2017). Spiritual and moral reform of Muslim inmates: The Nursi Model. In I. S., Markham, \& Z. Sayllgan (Ed.), The Companion to Said Nursi Studies (pp. 305-321). Eugene, Oregon: Pickwick Publications.

Carter, S. K. (1994). Russian nationalism: Yesterday, today, tomorrow. London: Pinter Publishers. 


\section{Said Nursi's views on ethnic nationalism 83}

Hashmi, T. I. (2004). Islamic resurgence in Bangladesh: Genesis, dynamics and implications. In S. P. Limaye, M. Malik, \& R. G. Wirsing (Ed.), Religious radicalism and security in South Asia (pp. 35-72). Honolulu, HI: Asia-Pacific Center for Security Studies.

Hossain, I., \& Khan, M. H. (2006). The rift within an imagined community: Understanding nationalism(s) in Bangladesh. Asian Journal of Social Science, 34(2), 324-339.

Ibrahim, H. A. (2005). Bediuzzaman Nursi; An overview of his life and position towards globalization. Contemporary Islamic Political Thought; A study of eleven Islamic thinkers (pp. 51-68). Malaysia: Research Center, IIUM.

Islam, M. N., \& Islam, M. S. (2018). Islam, politics and secularism in Bangladesh: Contesting the dominant narratives. Social Sciences, 7(3), 37. DOI: $10.3390 /$ socsci7030037

Maniruzzaman, T. (1990). Bangladesh politics: Secular and Islamic trends in religion, nationalism and politics in Bangladesh (pp.62-93). New Delhi: South Asian Publishers.

Mohsin, A. A. (2004). Religion, politics and security: The case of Bangladesh. In S. P. Limaye, R. G. Wirsing, \& M. Malik (Ed.), Religious Radicalism and Security in South Asia (pp. 470). Honolulu HI: Asia-Pacific Center for Security Studies.

Nereid, C. T. (2000). In the light of Said Nursi: Turkish nationalism and the religious alternative (Bergen Studies on the Middle East \& Africa). London: C. Hurst \& Co. Publishers Ltd.

Nursi, S. (1989). The Damascus Sermon. Istanbul: Sözler Publications.

Nursi, S. (1995). Risale-i Nur Collection, Volume 3: The Flashes Collection. USA: Nur Publishers.

Orwell, G. (1953). Notes on Nationalism. In Such, such were the joys. New York: Harcourt, Brace and Company.

Riaz, A. (2002). Nations, nation-state and politics of Muslim identity in South Asia. Comparative Studies of South Asia, Africa and Middle East, 22(1-2), 53-58. https://doi.org/10.1215/1089201X-22-1-2-53

Riaz, A. (2003). God Willing: The politics and ideology of Islamism in Bangladesh. Comparative Studies of South Asia, Africa and Middle East, 23(1), 301-320. https://doi.org/10.1215/1089201X-23-1-2-301

Riaz, A., \& Fair, C. (Ed.). (2011). Political Islam and governance in Bangladesh. London and New York: Routledge.

Taylor, C. (1994). The politics of recognition. In Multiculturalism: Examining the politics of recognition (pp. 30-32). Princeton: Princeton University Press. 
84 IIUC Studies, 14(2)

Triandafyllidou, A. (1998). National identity and the other. Ethnic and Racial Studies, 21(4), 593-612. DOI: 10.1080/014198798329784

White, R. (2005). Herder: On the ethics of nationalism. Humanitas, 18(1-2), 166181.

\section{Corresponding author}

Sumaiya Rabeya can be contacted at: sumaiyarabeya@gmail.com 